\title{
Analysis and Prediction of Meteorological Drought Area by Using Standardized Precipitation Index in Northeast, Thailand
}

\author{
Sirimanee Kornkosa, Nutthakarn Phumkokrux, Patiya Pattanasak, and Supaporn Manajitprasert
}

\begin{abstract}
The objectives of this work are: 1) to monitor the trend of rainfall data in in-season rice field period of Thailand (April to August). 2) to analyze meteorological drought by Standardized Precipitation Index : SPI in Northeast Thailand in in-season rice field period of Thailand and 3) to predict the rainfall data in in-season rice field period of Thailand of 2021. The average monthly rainfall data in April to August of 1990 2020 were gathered from 31 meteorological stations covered Northeast area of Thailand by Meteorological Department of Thailand. The data were used to draw trend of monthly average rainfall to track a change of rainfall in the period. Then, these were used to create distribution of meteorological drought characteristics maps under SPI criteria. Moreover, Single Moving Average model is used to predict the rainfall data with the lowest MAPE at 11.13 percentage. The results show that the higher meteorological drought risk area was always found in south-west side of the region in June to August. Moreover, average monthly rainfall increases from April and hit the peak in July and August. The trend of total monthly rainfall in in-season rice field period fluctuates along the study period with average value at 977.98 millimeters and its trend tends to be decreased at 0.1052 millimeters per year.
\end{abstract}

Index Terms-Meteorological drought, drought in Thailand, standardized precipitation index, rainfall change.

\section{INTRODUCTION}

Drought is one of major natural problem which many areas in Thailand must face in many years. This problem effect to ecosystem and various activities especially, agriculture. Northeast Thailand also faces with this problem every year because of the location of the area which is located far from ocean thus, humidity is hardly pass through the area to form rain. However, this area only gains rainfall from $2-3$ tropical cyclone which are transported to the area. Moreover, this area is covered by sandstone and Sandy soil thus, it is hard to storage the water for using in all activities. From this composition lead this region to face with drought [1].

One of agricultural activity which is wildly found in this region is rice faming. In 2018, there was 59,005 squares kilometers of rice filed in this region [2]. In-season rice field period of Thailand starts from April to August in every year and this activity need so much of water thus, water management is necessary in this period.

Standardized Precipitation Index or SPI is widely used to reflect the lacking in rainfall in the area which is the one of

Manuscript received July 27, 2021; revised August 17, 2021.

The authors are with the Department of Geography, Faculty of Education, Ramkhamhaeng University, Bangkok, Thailand (e-mail: sirimaneekornkosa@gmail.com, ph.nutthakarn@hotmail.com, patiya@ru.ac.th,Supaporn_m@ru.ac.th). important parameter to present the drought in the area. This index is simple method which using only average monthly rainfall data to analyze the drought characteristics over the area. If the SPI value is positive, it means there are high humidity due to higher rainfall, however; if SPI value is negative, it means the area has a chance to face with drought problem due to lower rainfall than usual [3].

From the problems which mentioned above bring authors to this work. The objectives of this work are 1) to monitor the trend of rainfall data in in in-season rice field period of Thailand (April to August). 2) to analyze meteorological drought by Standardized Precipitation Index : SPI in Northeast Thailand in in-season rice field period of Thailand from 1990 to 2020 and 3) to predict the rainfall data in in-season rice field period of Thailand of 2021. The results of this work can be used to manage the water in the area to protect drought risk.

\section{MATERIALS AND Methods}

\section{A. Study Area and Data}

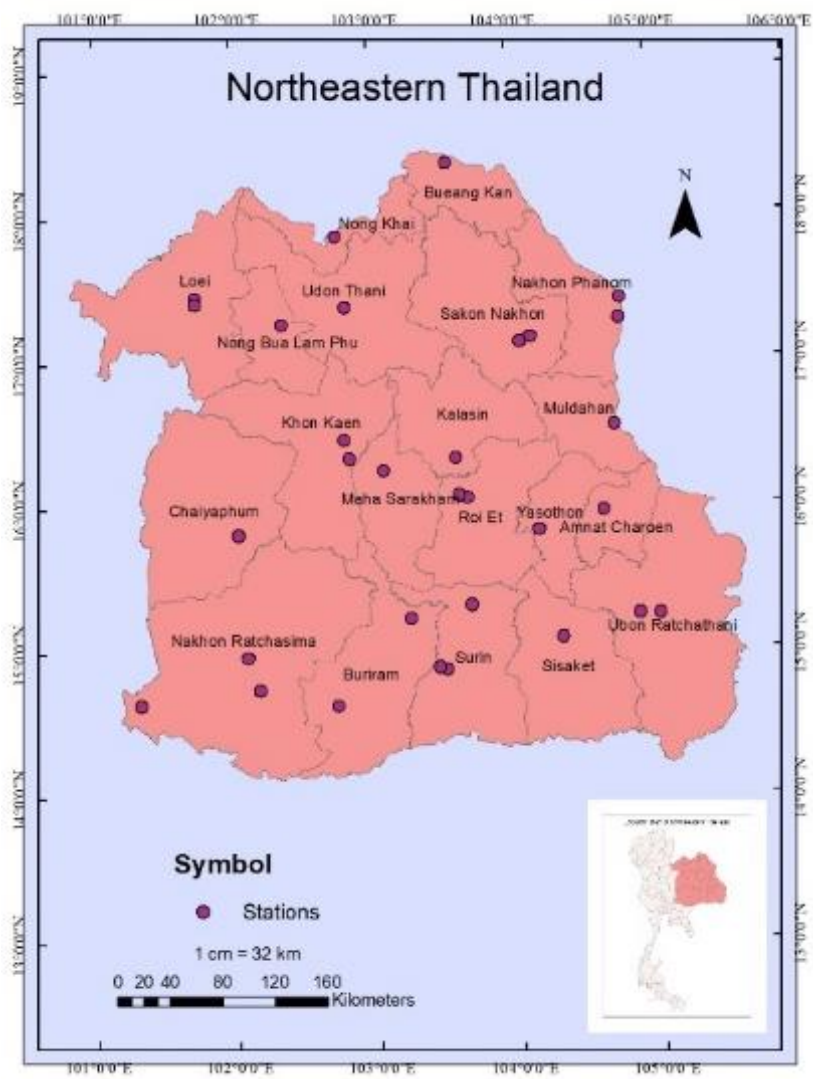

Fig. 1. Study area of Northeast of Thailand 
This work focused on Northeast area of Thailand, which was covered 20 provinces, around 10,218 square kilometers; defined by Thai Meteorological Department [1], [4]. The study area is presented in Fig.1. Moreover, the study used average monthly rainfall data in in-season rice field period of Thailand (April to August) from 1990 to 2020, which were collected by Thai Meteorological Department from 31 meteorological stations over northeast area of Thailand. The stations' location and detail are illustrated in Fig. 1 and Table I.

\begin{tabular}{|c|c|c|}
\hline \multicolumn{3}{|c|}{ THAILAND. [4] } \\
\hline Station No. & Lat. & Long. \\
\hline 48350 & $17^{\circ} 24^{\prime \prime} 34.6^{\prime} \mathrm{N}$ & $101^{\circ} 43^{\prime \prime} 46.9^{\prime} \mathrm{E}$ \\
\hline 48352 & $17^{\circ} 51^{\prime \prime} 49.8^{\prime} \mathrm{N}$ & $102^{\circ} 45^{\prime \prime} 3.1^{\prime} \mathrm{E}$ \\
\hline 48353 & $17^{\circ} 27^{\prime \prime} 9.3^{\prime} \mathrm{N}$ & $101^{\circ} 43^{\prime \prime} 50.5^{\prime} \mathrm{E}$ \\
\hline 48354 & $17^{\circ} 22^{\prime \prime} 37.5^{\prime} \mathrm{N}$ & $102^{\circ} 48^{\prime \prime} 34.6^{\prime} \mathrm{E}$ \\
\hline 48355 & $17^{\circ} 7^{\prime \prime} 30.1^{\prime} \mathrm{N}$ & $104^{\circ} 3^{\prime \prime} 39.6^{\prime} \mathrm{E}$ \\
\hline 48356 & $17^{\circ} 9^{\prime \prime} 17.5^{\prime} \mathrm{N}$ & $104^{\circ} 8^{\prime \prime} 13.3^{\prime} \mathrm{E}$ \\
\hline 48357 & $17^{\circ} 24^{\prime \prime} 38.5^{\prime} \mathrm{N}$ & $104^{\circ} 46^{\prime \prime} 57.3^{\prime} \mathrm{E}$ \\
\hline 48358 & $17^{\circ} 16^{\prime \prime} 35.1^{\prime} \mathrm{N}$ & $104^{\circ} 46^{\prime \prime} 25.2^{\prime} \mathrm{E}$ \\
\hline 48360 & $17^{\circ} 13^{\prime \prime} 56.6^{\prime} \mathrm{N}$ & $102^{\circ} 25^{\prime \prime} 46.4^{\prime} \mathrm{E}$ \\
\hline 48381 & $16^{\circ} 27^{\prime \prime} 39.7^{\prime} \mathrm{N}$ & $102^{\circ} 47^{\prime \prime} 22.6^{\prime} \mathrm{E}$ \\
\hline 48382 & $16^{\circ} 14^{\prime \prime} 43.3^{\prime} \mathrm{N}$ & $103^{\circ} 4^{\prime \prime} 10.7^{\prime} \mathrm{E}$ \\
\hline 48383 & $16^{\circ} 32^{\prime \prime} 29.9^{\prime} \mathrm{N}$ & $104^{\circ} 43^{\prime \prime} 44.7^{\prime} \mathrm{E}$ \\
\hline 48384 & $16^{\circ} 20^{\prime \prime} 7.6^{\prime} \mathrm{N}$ & $102^{\circ} 49^{\prime \prime} 36.1^{\prime} \mathrm{E}$ \\
\hline 48390 & $16^{\circ} 19^{\prime \prime} 55.3^{\prime} \mathrm{N}$ & $1.3^{\circ} 35^{\prime \prime} 15.1^{\prime} \mathrm{E}$ \\
\hline 48403 & $16^{\circ} 48^{\prime \prime} 42.9^{\prime} \mathrm{N}$ & $102^{\circ} 1^{\prime \prime} 45.1^{\prime} \mathrm{E}$ \\
\hline 48404 & $16^{\circ} 4^{\prime \prime} 23.6^{\prime} \mathrm{N}$ & $103^{\circ} 36^{\prime \prime} 30.4^{\prime} \mathrm{E}$ \\
\hline 48405 & $16^{\circ} 3^{\prime \prime} 6.5^{\prime} \mathrm{N}$ & $103^{\circ} 39^{\prime \prime} 51.8^{\prime} \mathrm{E}$ \\
\hline 48407 & $15^{\circ} 14^{\prime \prime} 38^{\prime} \mathrm{N}$ & $104^{\circ} 52^{\prime \prime} 29.5^{\prime} \mathrm{E}$ \\
\hline 48408 & $15^{\circ} 14^{\prime \prime} 20.9^{\prime} \mathrm{N}$ & $105^{\circ} 1^{\prime \prime} 24.6^{\prime} \mathrm{E}$ \\
\hline 48409 & $15^{\circ} 5^{\prime \prime} 7.1^{\prime} \mathrm{N}$ & $104^{\circ} 19^{\prime \prime} 50.3^{\prime} \mathrm{E}$ \\
\hline 48416 & $15^{\circ} 18^{\prime \prime} 58.6^{\prime} \mathrm{N}$ & $103^{\circ} 40^{\prime \prime} 49.3^{\prime} \mathrm{E}$ \\
\hline 48431 & $14^{\circ} 58^{\prime \prime} 5.9^{\prime} \mathrm{N}$ & $102^{\circ} 5^{\prime \prime} 9.7^{\prime} \mathrm{E}$ \\
\hline 48432 & $14^{\circ} 52^{\prime \prime} 26.2^{\prime} \mathrm{N}$ & $103^{\circ} 29^{\prime \prime} 58.7^{\prime} \mathrm{E}$ \\
\hline 48433 & $14^{\circ} 53^{\prime \prime} 27.4^{\prime} \mathrm{N}$ & $103^{\circ} 27^{\prime \prime} 8.9^{\prime} \mathrm{E}$ \\
\hline 48434 & $14^{\circ} 44^{\prime \prime} 16.7^{\prime} \mathrm{N}$ & $102^{\circ} 10^{\prime \prime} 5.2^{\prime} \mathrm{E}$ \\
\hline 48435 & $14^{\circ} 38^{\prime \prime} 31.4^{\prime} \mathrm{N}$ & $101^{\circ} 19^{\prime \prime} 17.4^{\prime} \mathrm{E}$ \\
\hline 48436 & $14^{\circ} 37^{\prime \prime} 51.5^{\prime} \mathrm{N}$ & $102^{\circ} 43^{\prime \prime} 16.9^{\prime} \mathrm{E}$ \\
\hline 48437 & $15^{\circ} 13^{\prime \prime} 32.7^{\prime} \mathrm{N}$ & $103^{\circ} 14^{\prime \prime} 53.1^{\prime} \mathrm{E}$ \\
\hline 48363 & $18^{\circ} 24^{\prime \prime} 49^{\prime} \mathrm{N}$ & $103^{\circ} 31^{\prime \prime} 0.2^{\prime} \mathrm{E}$ \\
\hline 48391 & $15^{\circ} 54^{\prime \prime} 13.5^{\prime} \mathrm{N}$ & $104^{\circ} 37^{\prime \prime} 5^{\prime} \mathrm{E}$ \\
\hline 48406 & $15^{\circ} 47^{\prime \prime} 41.8^{\prime} \mathrm{N}$ & $104^{\circ} 12^{\prime \prime} 51.7^{\prime} \mathrm{E}$ \\
\hline
\end{tabular}

\section{B. Meteorological Drought Monitoring by SPI}

There are two steps to monitor drought risk in this work. Firstly, average monthly rainfall data of 1990 to 2020 in April to August of Northeast of Thailand were gathered to draw line graph of average monthly rainfall trend of April to August and total rainfall trend of in-season rice field period of Thailand to monitor a change of rainfall in this season by using Linear method. This step was prepared by excel program. For the next step, all average monthly rainfall data were used to detect drought area under SPI criteria as the Eq. (1) [3], [5]-[7]. Then, all SPI index results after using this equation were categorized by the criteria in table II.

$$
\mathrm{SPI}=\frac{X_{i j}-X_{i m}}{\sigma}
$$

whereas; $X_{i j}$ is average monthly rainfall data of each month of each meteorological station, $X_{i m}$ is average monthly rainfall data of each month of all meteorological stations which are used in the work and $\sigma$ is standard deviation of average monthly rainfall data.
Then, the meteorological drought maps were draw by raster interpolation method. (Kriging) to present the distribution of drought characteristics in the area in each month and each year. Drought analysis is necessary from this process.

TABLE II: DROUGHT CHARACTERISTICS BY SPI CRITERIA. [3], [6]

\begin{tabular}{lccc}
\hline $\begin{array}{c}\text { Drought } \\
\text { characteristics }\end{array}$ & $\begin{array}{c}\text { SPI } \\
\text { Index }\end{array}$ & Weight & $\begin{array}{c}\text { Color in } \\
\text { Map }\end{array}$ \\
\hline No drought & $\begin{array}{c}0.01 \text { to } \\
2.00\end{array}$ & 1 & \\
Mild drought & -0.99 to & 2 \\
& 0.00 & \\
Moderate & -1.00 to & 3 \\
drought & 1.49 & \\
Severe drought & -1.50 to & 4 \\
& -1.99 & \\
Extreme & $<-2.00$ & 5 \\
drought & & \\
\hline
\end{tabular}

\section{Meteorological Drought Prediction by SPI in 2021}

There are three equations which can be used to forecast the average monthly rainfall data, which are Single Moving Average model as Eq. (2) [7] - [8], Simple Exponential Smoothing model as Eq. (3) [7] - [10] and Double Exponential Smoothing (Holt's model) as Eq. (4), (5), (6). [7], [11]

$$
\begin{gathered}
F_{t+1}=\frac{X_{t}+X_{t-1}+\cdots+X_{t-n+1}}{n} \\
F_{t+1}=F_{t}+\alpha\left(X_{t}-F_{t}\right) \\
F_{t+m}=S_{t}+b_{t} m \\
S_{t}=\alpha X_{t}+(1-\alpha)\left(S_{t-1}+b_{t-1}\right) \\
b_{t}=\delta\left(S_{t}-\left(S_{t-1}\right)\right)+(1-\delta) b_{t-1}
\end{gathered}
$$

whereas $F t$ is the predicted rainfall in time $t, X t$ is the observation rainfall in time $t$ and $n$ is the number of times which are used to calculate the average rainfall. $\alpha$ is the constant smoothing parameter and significance or weight given to the data in time $t$, while a range from 0 to 1 . If $\alpha$ is low, more weight will be given to data in the past. If $\alpha$ is high, more weight will be given to recent data. $m$ is the future time and equal to $1 . \delta$ is the smoothing constant for the actual and estimated trend.

The rainfall prediction data from these three equations were compared the error between observation data and predicted data by using the mean absolute percentage error (MAPE) as Eq. (7). The suitable equation which was selected to predict the rainfall data for drought risk analysis must give the lowest MAPE. [12]

$$
\text { MAPE }=\frac{\Sigma\left[\left|\frac{O_{t}-P_{t}}{O_{t}}\right|\right] \times 100}{n}
$$

whereas; $O_{t}$ is observation data, $P_{t}$ is Predicted data, $\mathrm{n}$ is number of total observation data or predicted data.

After the suitable equation is selected, the forecasting data will be calculated. Then, the predicted rainfall data of each month were used to define the drought by using SPI criteria as in Eq.1 and Table II. Next, meteorological drought maps 
using SPI will be created to present the distribution of drought characteristics over the region. From this process, drought prediction analysis is performed.

\section{RESULTS}

\section{A. Meteorological Drought Analysis by SPI in the Past (1990-2020)}

\section{1) Rainfall change and its trends}

The rainfall trends of each month were created by excel program to monitor the rainfall change of April to August in the study area. The line graphs of fig. 2 (upper) presented that the monthly average rainfall started to rise from April then, it gradually increased and hit the peak in July and August of each year. Furthermore, the average monthly rainfall of these five months was about 195.60 millimeters. However, trend of total rainfall of this region in in-season rice field period of Thailand (April to August) was built by linear method as shown in Fig. 2 (Lower). The trend of total rainfall was fluctuated with the total rainfall averaging at 977.98 millimeters. Moreover, the total rainfall decreased by 0.1052 millimeters per year.

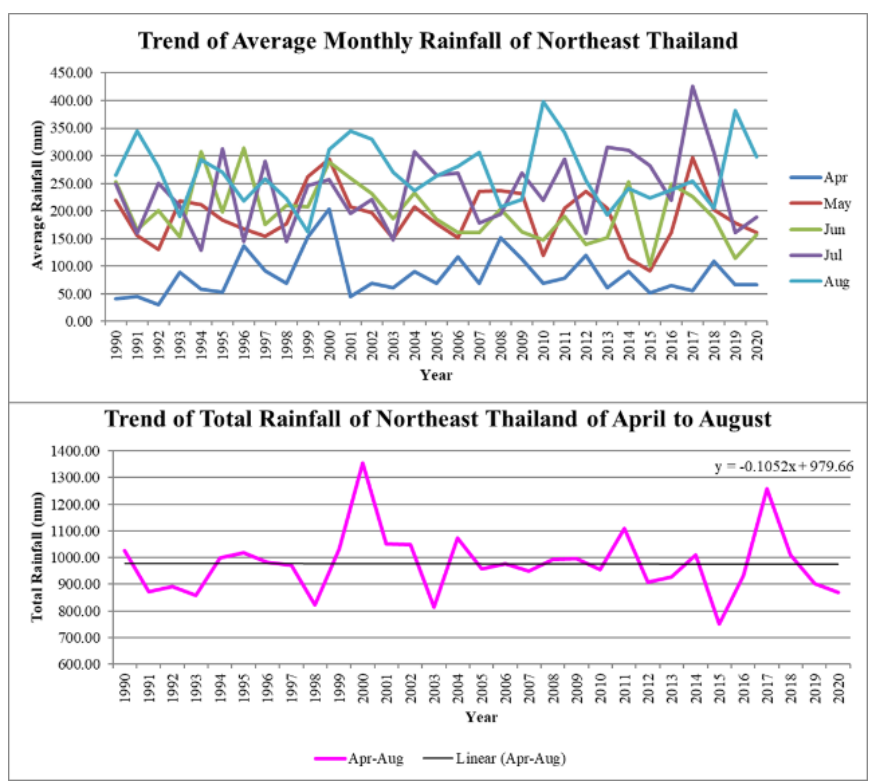

Fig. 2. (Upper) trend of average monthly rainfall of Northeast Thailand in April to August. (Lower) trend of total rainfall of Northeast Thailand of in-season rice field period.

\section{2) Meteorological drought analysis}

The meteorological drought maps of each month in this study period using SPI as illustrated in Fig. 3 - 7 were created by raster interpolation method (Kriging). The maps of April, May, June, July, and August presented that area of Mild drought level are the largest area in all maps following by the area of No drought level, Moderate drought level, Severe drought level and Extreme drought level, respectively. However, there are no exact drought patterns of April and May in this region. In contrast, the drought area of June, July and August is always distributed around south-west side of region especially, Nakhon Ratchasima, Chaiyaphum, Buriram and Khon khan Province. The severe drought level and extreme drought level are seldom found in May 2004, June 1995, June 2000, and July 2013.

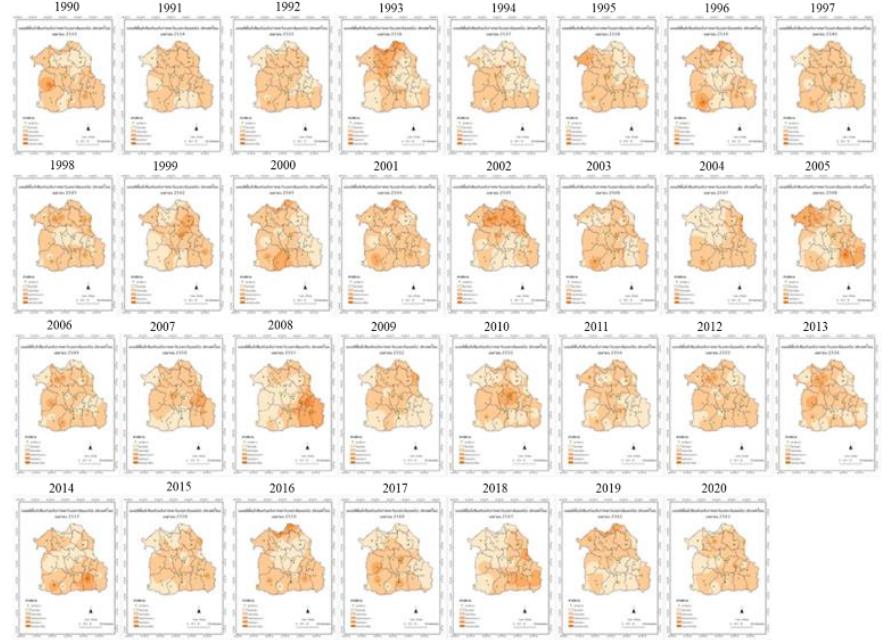

Fig. 3. Meteorological drought maps using SPI in April of 1990 to 2020.

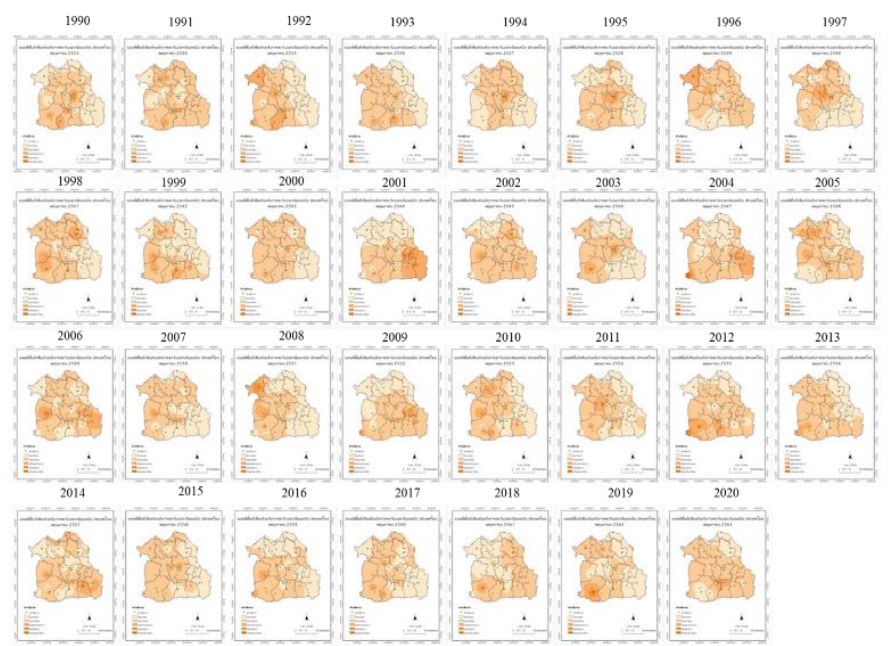

Fig. 4. Meteorological drought maps using SPI in May of 1990 to 2020.

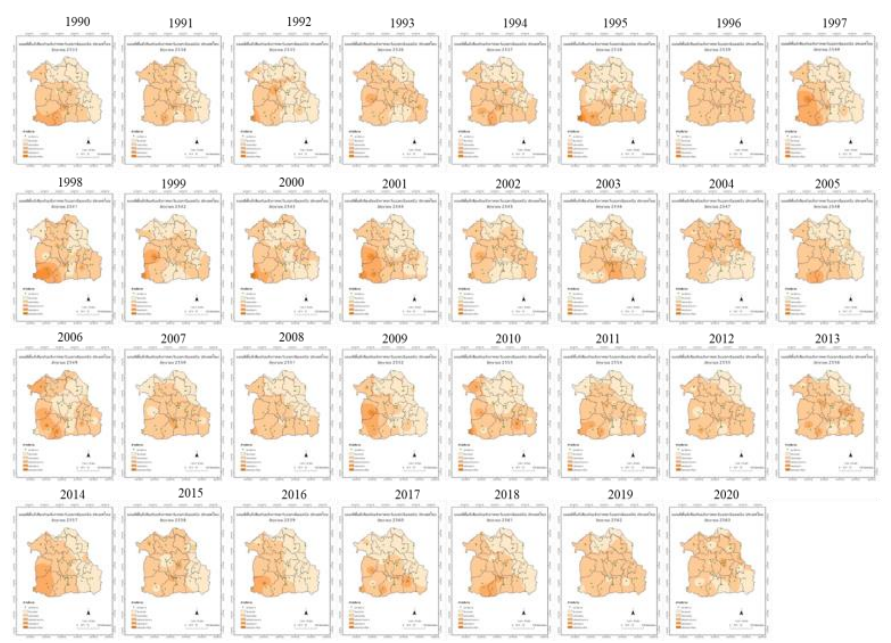

Fig. 5. Meteorological drought maps using SPI in June of 1990 to 2020.

\section{B. Meteorological Drought Prediction by SPI of 2021}

There are three equations for monthly rainfall forecasting: Single Moving Average model, Simple Exponential Smoothing Model and Double Exponential Smoothing. These equations were compared an error between observation data and Forecasting data by MAPE as Eq. (7). The results show that Single Moving Average model is a suitable equation to predict monthly rainfall data by giving the lowest MAPE with 11.13 percentage as presented in Table III. Therefore, Single Moving Average model was used 
to predict the monthly rainfall data of April to August in 2021 and the predicted data were illustrated in Table IV.

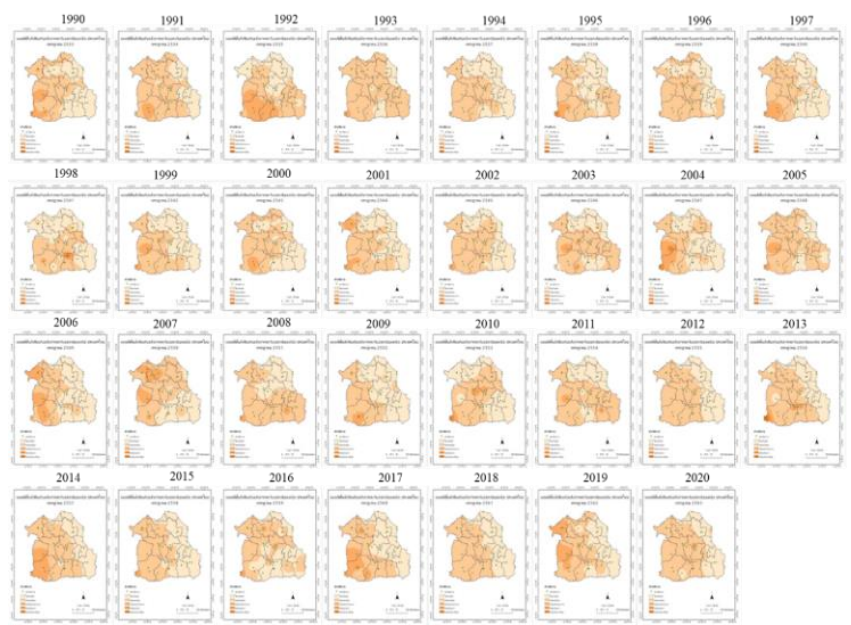

Fig. 6. Meteorological drought maps using SPI in July of 1990 to 2020.

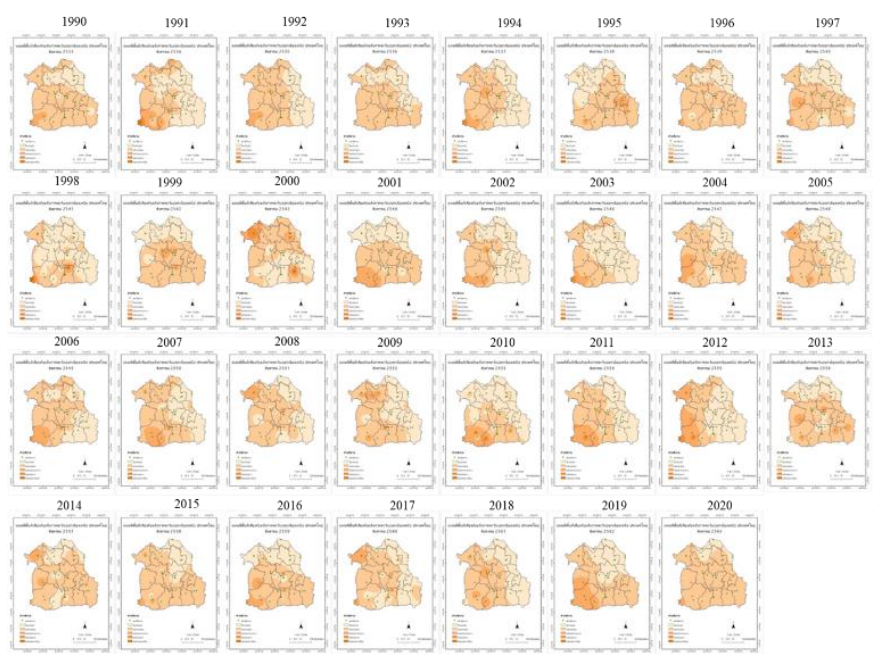

Fig. 7. Meteorological drought maps using SPI in August of 1990 to 2020.

Meteorological drought maps of April to August in 2021 using SPI were created to analyze meteorological drought risk area in Northeast Thailand as illustrated in Fig. 8. The map of April 2021 presented that the area of Mild drought level is largest area in this month with 63.46 percentage of area following by No Drought Level, Moderate Drought Level and Severe Drought with 27.87, 8.16 and 0.52 percentage of area, respectively. Moreover, the most drought risk area is usually located around the boundary of region especially in east side of area. Then, the map of May 2021 illustrated that Mild drought level is largest area in this month with 59.93 percentage of area. Following by No Drought Level, Moderate Drought Level and Severe Drought with $32.40,7.18$ and 0.49 percentage of area, respectively. The most drought risk area distributed over the region especially, Nakhon Ratchasima Province. Next, the map of June, July and August 2021 explained that these maps have same drought pattern. The Mild drought level is largest area in this month. Following by No Drought Level and Moderate Drought Level. The most drought risk area is located at southwest of region; however, Severe Drought Level and Extreme Drought Level is not found in last 3 months of 2021. All predicted maps presented in Fig.8.
TABLE III: MEAN PERCENTAGE AbSOLUTE ERROR FROM MONTHLY RAINFALL PREDICTION EQUATION

\begin{tabular}{lc}
\hline \multicolumn{1}{c}{ Equation } & MPAE \\
\hline Single Moving Average model & 11.13 \\
\hline Simple Exponential Smoothing model & 11.74 \\
\hline Double Exponential Smoothing & 15.26 \\
\hline
\end{tabular}

TABLE IV: Monthly Rainfall Data, PRedicted By Single Moving AVERAGE MODEL

\begin{tabular}{cccccc}
\hline Station No. & Apr & May & Jun & Jul & Aug \\
\hline $\mathbf{4 8 3 5 0}$ & 71.42 & 179.04 & 156.18 & 157.28 & 218.84 \\
$\mathbf{4 8 3 5 2}$ & 61.86 & 301.28 & 243.44 & 308.48 & 488.64 \\
$\mathbf{4 8 3 5 3}$ & 68.70 & 195.80 & 155.04 & 174.04 & 209.00 \\
$\mathbf{4 8 3 5 4}$ & 67.72 & 216.14 & 251.86 & 196.24 & 309.58 \\
$\mathbf{4 8 3 5 5}$ & 70.58 & 272.10 & 208.90 & 391.12 & 313.88 \\
$\mathbf{4 8 3 5 6}$ & 62.12 & 185.60 & 273.00 & 403.64 & 283.46 \\
$\mathbf{4 8 3 5 7}$ & 103.84 & 247.84 & 326.56 & 584.16 & 500.36 \\
$\mathbf{4 8 3 5 8}$ & 87.80 & 194.84 & 257.06 & 542.70 & 420.32 \\
$\mathbf{4 8 3 6 0}$ & 80.08 & 210.64 & 183.96 & 136.50 & 243.64 \\
$\mathbf{4 8 3 8 1}$ & 87.88 & 165.16 & 159.56 & 190.30 & 193.86 \\
$\mathbf{4 8 3 8 2}$ & 109.74 & 208.40 & 136.02 & 249.16 & 318.20 \\
$\mathbf{4 8 3 8 3}$ & 37.66 & 155.76 & 219.06 & 415.78 & 377.20 \\
$\mathbf{4 8 3 8 4}$ & 77.72 & 229.46 & 167.18 & 176.64 & 182.94 \\
$\mathbf{4 8 3 9 0}$ & 54.26 & 190.10 & 151.78 & 237.36 & 275.44 \\
$\mathbf{4 8 4 0 3}$ & 71.56 & 172.78 & 127.98 & 129.94 & 150.90 \\
$\mathbf{4 8 4 0 4}$ & 89.36 & 181.82 & 152.12 & 208.60 & 347.58 \\
$\mathbf{4 8 4 0 7}$ & 79.08 & 245.40 & 267.76 & 314.46 & 285.94 \\
$\mathbf{4 8 4 0 8}$ & 44.02 & 219.92 & 282.34 & 312.40 & 263.54 \\
$\mathbf{4 8 4 0 9}$ & 47.00 & 222.12 & 159.36 & 265.32 & 247.96 \\
$\mathbf{4 8 4 1 6}$ & 76.62 & 161.10 & 130.54 & 228.68 & 206.80 \\
$\mathbf{4 8 4 3 1}$ & 45.70 & 148.82 & 149.34 & 133.62 & 185.88 \\
$\mathbf{4 8 4 3 2}$ & 47.14 & 192.14 & 172.10 & 219.70 & 260.22 \\
$\mathbf{4 8 4 3 3}$ & 61.46 & 178.74 & 167.10 & 234.54 & 220.44 \\
$\mathbf{4 8 4 3 4}$ & 67.20 & 139.68 & 133.28 & 102.36 & 135.62 \\
$\mathbf{4 8 4 3 5}$ & 90.28 & 176.44 & 119.28 & 117.16 & 146.76 \\
$\mathbf{4 8 4 3 6}$ & 81.16 & 171.08 & 99.76 & 199.32 & 187.28 \\
$\mathbf{4 8 4 3 7}$ & 64.84 & 214.24 & 167.36 & 187.48 & 209.26 \\
\hline & & & & & \\
\hline
\end{tabular}

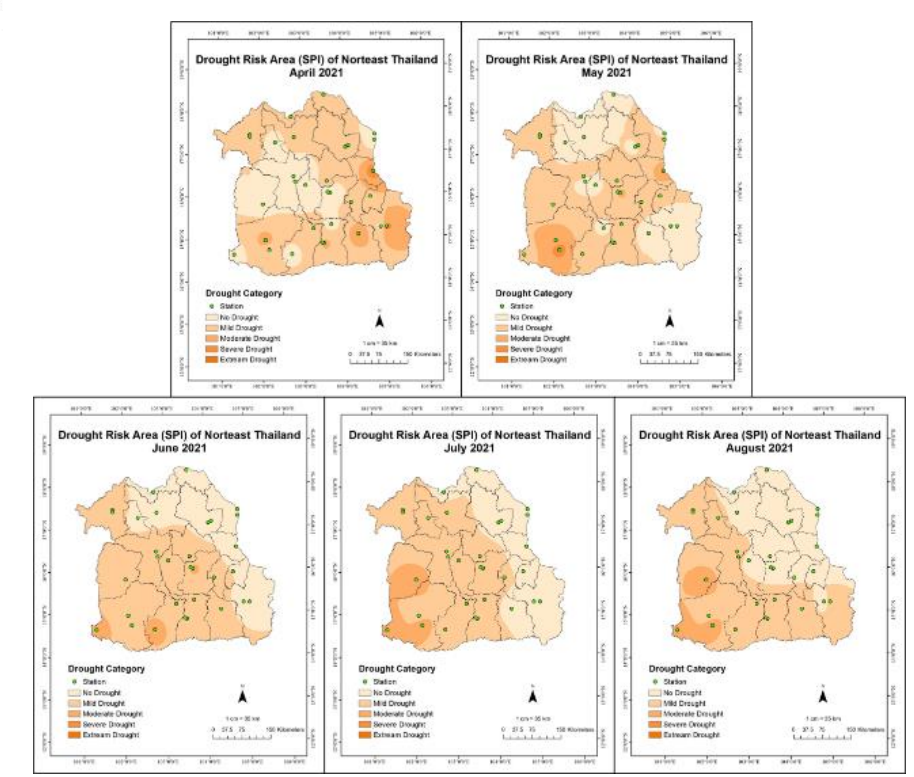

Fig. 8. Meteorological drought maps of April to August in 2021.

\section{DISCUSSION AND CONCLUSION}

The drought risk in in-season rice field period of Thailand (April to August) from 1990 to 2020 was important to monitor because of the needs of water for agriculture especially, rice. For the trend line of rainfall in this period prove that the rainfall has the change to dwindle by 0.1052 millimeters per year. This can prove that the rainfall situation in this region has the chance to face with drought risk problem in the future. There were no patterns for 
meteorological drought characteristics under SPI criteria in April and May because of Thunderstorms cannot be predicted. However, there were exact drought characteristics pattern in June to August. The higher drought level was located around south-west side of the region then, it was decreased around east side of study area. This phenomenon always happened because of tropical clone which always pass-through Northeast region in this period by the east side thus, it is normal that east side of the area has lower chance than west side to face with drought risk.

For the drawback of this work, only average monthly rainfall data in Northeast area were used to analyze the meteorological drought by using just SPI method. This might not be enough to monitor the exact impact of drought risk in this region. However, there are many methods to monitor the drought in Thailand such as Generalized Monsoon Index (GMI) and Meteorological Drought Index or D method with different types of data such as air temperature, topography pattern, slope pattern, human activities, relative humidity, Land use pattern, evaporation, etc.

\section{CONFLICT OF INTEREST}

The authors declare no conflict of interest.

\section{AUTHOR CONTRIBUTIONS}

SK and NP conceived and designed the analysis of research. SK gathered all meteorological data and performed research. SK and NP discussed the results and contributed to the manuscript. PP and SM had approved the final version and gave all recommendations.

\section{ACKNOWLEDGMENT}

The authors would like to thank you to Thai Meteorological Department for all necessary data which using in this study. And the authors appreciate to Department of Geography, Faculty of Education, Ramkhamhaeng University for all important knowledge.

\section{REFERENCES}

[1] Thai Meteorological Department. (2019). Climate of Thailand. [Online]. Available: https://www.tmd.go.th/info/info.php?FileID

[2] Office of Agricultural Economics. (2020). Agricultural economic data. [Online]. Available: http://mis-app.oae.go.th/area/

[3] T.B. McKee, N. J. Doesken, and J. Kleist, "The relationship of drought frequency and duration to time scales," in Proc. the Eighth Conference on Applied Climatology. Anaheim, CA, USA. pp. 179-186, 1993.

[4] Thai Meteorological Department. (2019). Summary of Climate data. [Online].

Available: https://www.tmd.go.th/cis/stats.php?method=stat_PrintStatSummary

[5] T. Chomtha. (November 2006). A Study of meteorological drought index model for drought areas in Northeastern Thailand. Technical Document No. 551.577.3-01-2007 of Meteorological Department, Bangkok, Thailand. [Online]. Available: http://www.arcims.tmd.go.th/Research_files/Drought.pdf

[6] World Meteorological Organization, Standardized Precipitation Index, World Meteorological Organization, Geneva, Switzerland, 2012.

[7] P. Wichitarapongsakun, C. Sarin, P. Klomjek, and S. Chuenchooklinb, "Rainfall prediction and meteorological drought analysis in the Sakae Krang River basin of Thailand," Agriculture and Natural Resources, vol. 50, no. 6, pp. 1-9, November 2016.
[8] N. H. Mohamed, A. Ismail, Z. Ismail, C. Adnan and M. Raji, "Trend analysis and forecasting of rainfall and floods in the Klang valley," Def. ST Tech. Bull, vol. 7, no. 2, pp. 112-120, January 2014.

[9] E. Pagourtzi, K. Nikolopoulos, and V. Assimakopoulos, "GFIS (Geographic Forecasting Information System): A case study in water resource management," Global Nest: the Int. J., vol. 5, no. 2, pp. 57-63, September 2003

[10] N. Sopipan, "Forecasting rainfall in Thailand: A case study of Nakhon Ratchasima province," International Journal of Environmental, Ecological, Geological and Marine Engineering, vol. 8, no. 11, pp 717-721, November 2014.

[11] M. Jahani, B. Salahi, and M.T. Masomi, "Germi county seasonal precipitation routing and analysis, using Holt-Winters method for time series with nonseasonal changes," Tech. J. Engin. App. Sci., vol. 3. pp. 950-953, 2013

[12] Agricultural and Meteorological Software. (2020). MAPE (Mean Absolute Percentage Error). [Online]. Available: https://agrimetsoft.com/calculators/Mean\%20Absolute\%20Percentage $\% 20$ Error

Copyright (C) 2021 by the authors. This is an open access article distributed under the Creative Commons Attribution License which permits unrestricted use, distribution, and reproduction in any medium, provided the original work is properly cited (CC BY 4.0).

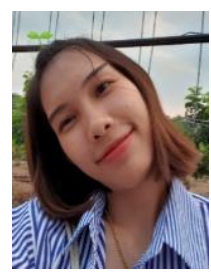

Sirimanee Kornkosa was born in Ubon Ratchathani, Thailand in 1996. She is now senior student who is studying bachelor of science degree program in geography at Department of Geography, Faculty of Education, Ramkhamhaeng University, Bangkok, Thailand. Her expertise is climatology and weather forecast. She is now working at Meteorological Department of Thailand.

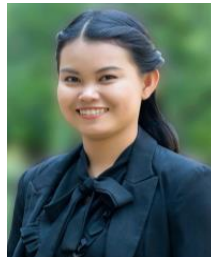

Nutthakarn Phumkokrux was born in Bangkok, Thailand in 1993. She received her bachelor of science degree program in geography from Ramkhamhaeng University, Bangkok, Thailand in 2014. Then, she earned her master of engineering degree in georesource engineering from Chulalongkorn University, Bangkok, Thailand in 2016. She is now working as a lecturer in Department of Geography, Faculty of Education, Ramkhamhaeng University, Bangkok, Thailand. Her expertise is climate change, geomorphology and carbon dioxide capture \& storage. She had been working as internship student at Division of Sustainable Resources Engineering, Graduate School of Engineering, Hokkaido University.

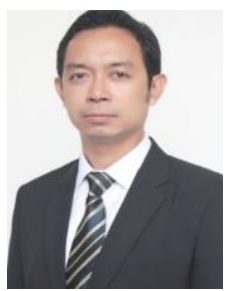

Patiya Pattanasak was born in Chiang Mai, Thailand in 1976. He received her bachelor of science degree in geography from Chiang Mai University, Thailand in 1998. Then, he earned her master's degree in geography from Chulalongkorn University, Bangkok, Thailand in 2001. Then, he finished Ph.D. program in sustainable land use and natural resource management from Kasetsart University. He is now working as a lecturer in the Department of Geography, Faculty of Education, Ramkhamhaeng University, Bangkok, Thailand. His expertise is remote sensing and land use detection.

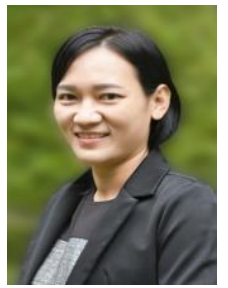

Supaporn Manajitprasert was born in Bangkok, Thailand in 1976. She received her bachelor of science degree in geography from Burapha University, Bangkok, Thailand in 1998. Then, she earned her master's degree in geography from Chulalongkorn University, Bangkok, Thailand in 2001. Then, she finished Ph.D. program in remote sensing \& GIS / School of Engineering and Technology from Asian Institute of Technology (AIT). She is now working as a lecturer in Department of Geography, Faculty of Education, Ramkhamhaeng University, Bangkok, Thailand. Her expertise is GIS and remote sensing. 